A RCHIWA, BIBLIOTEKI

I MUZEA KOŚCIELNE 109 (2018)

https://doi.org/10.31743/abmk.2018.109.19

WALDEMAR W. ŻUREK SDB* - LUBLIN

\title{
INWENTARZ RZYMSKOKATOLICKIEGO KOŚCIOLA PARAFIALNEGO W KOBRYNIU Z 21 SIERPNIA 1933 ROKU
}

Kresowe Miasto Kobryń położone jest nad rzekami: Muchawcem i Kobrynką, około 60 kilometrów na wschód od Brześcia. Przekazy historyczne na temat jego początku pochodzą z końca XIII w. Pierwszy drewniany kościół fundacji Anny Kobryńskiej-Kostewicz ${ }^{1}$ z 1500 r. (inne źródła podają, że fundatorem świątyni w Kobryniu był w 1513 r. król polski Zygmunt I), był wielokrotnie niszczony, głównie przez pożary. Świątynia odbudowana przez Hieronima Wołłowicza ${ }^{2}$

* Ks. Waldemar Witold Żurek SDB - dr hab. historii Kościoła, prof. KUL; dyrektor Ośrodka Archiwów, Bibliotek i Muzeów Kościelnych KUL; e-mail: zurek@kul.pl

${ }^{1}$ Anna Kostewicz była w pierwszym małżeństwie żoną wojewody moskiewskiego Fiodora, księcia bielskiego, córką księcia kobryńskiego, prawnuka wielkiego księcia litewskiego Olgierda. Następnie została pierwszą żoną ostatniego księcia kobryńskiego - Wacława Stankiewicza Kostewicz, zmarłego w 1532 r., marszałka królewskiego (1511 r.), marszałka hospodarskiego (1509 r. lub 1511 r.), dzierżawcy kobryńskiego, starosty kobryńskiego. W 1512 r. Anna otrzymała księstwo kobryńskie po zmarłej bratowej - Fiodorze (Zofii) z Rohatyńskich. W 1516 r. Wacław Kostewicz otrzymał od króla, po śmierci pierwszej żony Anny, księstwo kobryńskie w dożywotnią dzierżawę. Mimo tego w 1522 r. Zygmunt Stary dał przywilej na księstwo kobryńskie królowej Bonie. Kostewicz nie zrezygnował jednak z dożywocia na Kobryniu, ale Bona w 1528 r. wymogła na nim rezygnację z księstwa, w zamian czego został on pierwszym starostą kobryńskim. Po śmierci żony Anny Kostewicz, ożenił się z Anną Iliniczówną, córką Mikołaja, syna starosty smoleńskiego Mikołaja i Elżbiety Niemirowicz-Szczytówny. Wacław Stankiewicz Kostewicz zmarł w 1532 roku. Po jego śmierci królowa Bona przejęła księstwo kobryńskie, które z dobra lennego za czasów książąt kobryńskich stało się dobrami „stołu królewskiego”. Wacław Kostewicz, w: Polski Słownik Biograficzny, t. 14, Wrocław 1968-1969, s. 344-345.

${ }^{2}$ Hieronim (Jarosz) Wołłowicz herbu Bogoria (†1643 r.) - starosta generalny żmudzki w 1619 r., podkanclerzy litewski w 1618 r., podskarbi litewski w 1605 r., podskarbi nadworny litewski w $1600 \mathrm{r}$., pisarz wielki litewski w latach 1598-1618, sekretarz Jego Królewskiej Mości. Był bratem biskupa wileńskiego Eustachego Wołłowicza i starosty grodzieńskiego Pawła Wołłowicza. Studiował na Uniwersytecie w Ingolstadt, w Altddorfie w 1578 r. (Niemcy) oraz w Padwie w 1593 r. Założył parafię w Zalesiu, a testamentem nadał w 1602 r. temu kościołowi folwark z zabudowaniami $\mathrm{w}$ tej miejscowości oraz wsie Zalesie i Pohorany. Fundację tę zatwierdził król Zygmunt III Waza. 
w 1625 r., kanclerza i skarbnika litewskiego oraz dzierżawcę królewskiego uległa kolejnemu zniszczeniu w czasie wojny napoleońskiej w $1812 \mathrm{r}^{3} \mathrm{~W}$ tym samym roku wybudowano w pobliżu Rynku kolejny drewniany kościół, nazywany szpitalnym. Po kilku latach prac, w 1846 r. staraniem tamtejszego proboszcza ks. Antoniego Kisielewskiego ${ }^{4}$ i z pomocą parafian, wybudowano na przedmieściu murowany kościół pw. Wniebowzięcia Najświętszej Maryi Panny, według projektu architekta Noskowa. Konsekracji świątyni dokonał w 1851 r. biskup wileński Wacław Żyliński ${ }^{5}$. Posiadała ona patronat duchowny ${ }^{6}$.

W 1618 r. Wołłowicz przeniósł uposażenie parafii na klasztor bernardynek w Grodnie. W 1617 r., na polecenie króla Zygmunta III Wazy, zbudował w Sokolnikach drewniany kościół i plebanię oraz wymierzył grunta pod przyszłe uposażenie parafii. Był elektorem Władysława IV Wazy z Księstwa Żmudzkiego w 1632 r. https://pl.wikipedia.org/wiki/Hieronim_Wo\%C5\%82\%C5\%82owicz (dostęp: 15.05.2018).

${ }^{3}$ Inwazja na Rosję w 1812 r. nazywana jest drugą wojną polską. Rozpoczęła się 24 czerwca, a zakończyła się 25 grudnia.W historiografii rosyjskiej zwana jest wojną ojczyźnianą 1812 r. Napoleon chcąc zmusić cara Aleksandra I do kontynuowania blokady kontynentalnej Anglii, zdecydował się na wojnę, podczas gdy car Rosji był niezadowolony z dominacji Francji w Europie. Napoleon zakładał, że sprawę rozstrzygnie w czasie jednej bitwy jego wielonarodowej armii (600.000 żołnierzy) z armią rosyjską dowodzoną przez Michaiła Kutuzowa. Rosjanie zastosowali strategię wciągania przeciwnika w głąb Rosji. Mimo zwycięskiej bitwy pod Borodino (5-7 września 1812 r.) i zajęcia Moskwy, armia francuska musiała się wycofać z powodu przedwczesnej zimy i braku żywności, tym bardziej, że większość budynków Moskwy strawiły pożary. W tej sytuacji Napoleon zarządził odwrót, który zapoczątkował jego klęska. Duże straty liczebne w armii poniósł w czasie przeprawy przez Berezynę. Ostatecznie porzucił resztki armii, udał się do Francji, a klęska moskiewska spowodowała jego całkowity upadek. M. Kukiel, Wojna 1812, Poznań 1996.

${ }^{4}$ Ksiądz Kisielewski Antoni, proboszcz w Kobryniu, odbudował zniszczony w czasie kampanii napoleońskiej w 1812 r. kościół parafialny.

${ }^{5}$ Żyliński Wacław (1803-1863) - ordynariusz wileński, arcybiskup mohylewski. Urodził się w rodowym majątku w Niedzingach, parafii i powiatu trockiego. Od 1820 r. studiował w seminarium duchownym w Mińsku i na Uniwersytecie Wileńskim. Święcenia kapłańskie przyjął dnia 2 kwietnia 1826 r. Po święceniach pracował jako wikariusz i kaznodzieja w katedrze w Mińsku, był proboszczem w Iwieńcu, wykładowcą i rektorem seminarium mińskiego. Jako kanonik miński w 1830 r. został przedstawicielem diecezji mińskiej, następnie wileńskiej (do której przeszedł w 1832 r.) przy Kolegium Duchownym Rzymskokatolickim w Petersburgu. Równocześnie był tam proboszczem parafii pw. św. Jana Chrzciciela i nauczycielem w szkole. W 1844 r. został członkiem Kolegium Duchownego w Petersburgu. Odznaczał się lojalnością wobec władz carskich. W 1846 r. został rządcą diecezji wileńskiej po śmierci biskupa Jana Kajetana Cywińskiego. Na początku lipca 1848 r. otrzymał prekonizację papieską na ordynariusza diecezji wileńskiej, po siedmiu latach wakansu. Sakrę biskupią przyjął w Petersburgu. Jego ingres odbył w styczniu 1849 r. Przejął diecezję po biskupie Andrzeju Benedykcie Kłągiewiczu. Z gorliwością odprawiał wizytacje parafialne, do wiernych kierował często listy pasterskie. Dnia 18 września 1856 r. bp Żyliński został nominowany na stolicę arcybiskupią mohylowską. Jednak na prośby kapituły rządził diecezją wileńską jeszcze do września 1858 r., do objęcia jej przez bpa A.S. Krasińskiego. Posłuszny decyzji cara Mikołaja I zakazał duchowieństwu rzymskokatolickiemu posługi unitom, za co został upomniany listem apostolskim z 21 kwietnia 1859 r. Zmarł w Petersburgu. Pochowany został w Niedzingach. Biskupstwo Wileńskie, opr. J. Kurczewski, Wilno 1912, s. 69-70; S. Brzozecki, Żyliński Wacław, w: Encyklopedia Katolicka, t. 20, Lublin 2014, kol. 1654-1655.

${ }^{6}$ Kobryń, w: Stownik Geograficzny Królestwa Polskiego, t. 4, Warszawa 1883, s. 205-207. 
Kościół wybudowany został na czteromorgowej parceli, która obwarowana była z trzech stron wałami ziemnymi, od drogi (ul. 3 Maja) murem, a od ul. Kościelnej płotem z siatki drucianej. Posiadała dwie wieże, a jej dach osadzony był na ośmiu filarach. Wewnątrz świątyni znajdowały się trzy ołtarze: Jezusa Chrystusa, Matki Bożej Ostrobramskiej i św. Antoniego. Na chórze stały 13 głosowe organy.

Katolicy w Kobryniu stanowili zdecydowaną mniejszość. Pod koniec XIX w. na ok. 7.800 mieszkańców miasta, katolicy stanowili $6 \%$ wiernych, prawosławni $36 \%$, a Żydzi 57,8 \%?.

Parafia kobryńska należała do diecezji łuckiej, w województwie brzeskolitewkim, w gubernii grodzieńskiej. Od sierpnia 1798 r. przeszła do diecezji wileńskiej $^{8}$.

W latach międzywojennych ubiegłego stulecia, w kościele tym znajdował się cudowny obraz Zbawiciela. Na terenie parafii były dwie kaplice: w Guberni (vel Nowosady) i w Hruszewie.

Po pierwszej wojnie światowej Kobryń powrócił w granice Polski. W okresie międzywojennym liczba wiernych katolików wynosiła w mieście ok. 3.500 osób. Proboszczami tamtejszej parafii byli księża: Bolesław Saperski, Jan Węckiewicz, Jan Wolski ${ }^{9}$.

Gdy po drugiej wojnie światowej Kobryń znalazł się w Białoruskiej Socjalistycznej Republice Radzieckiej, w mieście funkcjonował jedynie kościół pw. Wniebowzięcia Najświętszej Maryi Panny, którego proboszczem był ks. Józef Horodeński. W sierpniu 1948 r. został on aresztowany przez komunistyczne służby bezpieczeństwa, a po miesięcznym śledztwie skazany na 25 lat obozu pracy, konfiskatę mienia i pozbawienie praw publicznych na lat 5 . Po powrocie $\mathrm{w} 1955 \mathrm{r}$. ze zsyłki, podjął pracę duszpasterską w Kobryniu, obsługując także okoliczne parafie. W 1958 r. skazany został ponownie kolejnym wyrokiem. Po odbyciu kary zakazano mu powrotu do kobryńskiej parafii i ostatecznie zmuszono go do wyjazdu do Polskiej Rzeczypospolitej Ludowej.

${ }^{7}$ S. Litak, Kościót łaciński w Rzeczypospolitej około 1772 roku, Lublin 1996, s. 386.

${ }^{8}$ Trzy rozbiory Polski podzieliły diecezję łucką pomiędzy trzech zaborców. Najcięższy kryzys przeszła ta diecezja, wraz ze swą stolicą Łuckiem, w zaborze rosyjskim. Na mocy ukazu Katarzyny II z 6(17) września 1795 r. biskupstwo łuckie zostało całkowicie zniesione, a w jego miejsce utworzono diecezję pińską. Ta samowola carycy nie uzyskała nigdy sankcji kanonicznej. Ukaz Pawła I z 8 maja 1798 r. przywrócił diecezję do życia, a delegat apostolski Wawrzyniec Litta określił nowe jej granice na podstawie dekretu (De apostolica potestatis plenitude) z 8 sierpnia $1798 \mathrm{r}$. $\mathrm{Z}$ diecezji łuckiej do wileńskiej przeszło wówczas ok. 30 parafii. B. Kumor, Granice metropolii i diecezji polskich (966-1939), Lublin 1969-1971, s. 293-294.

${ }^{9}$ Ks. Wolski Jan - kapłan diecezji pińskiej. Urodził się w 1887 r. Święcenia kapłańskie przyjął w 1910 r. Był proboszczem i dziekanem w Kobryniu. Za pomoc Żydom, w 1943 r. został rozstrzelany przez Niemców przed kościołem w Kobryniu, wraz z grupą ludności żydowskiej. Według innej wersji zginął 15 października 1942 r., w dniu likwidacji getta, w lesie pod Borysowem. L. Mikhailik, Kościót katolickie na Grodzieńszczyźnie 1939-1956, Warszawa 2008, s. 286; Wolski Jan, w: Niech świadectwo nie będzie zapomniane. Losy Kościoła katolickiego na Białorusi w latach 1917-1953, red. R. Wierna, Grodno 2000, s. 82. 
W czerwcu 1962 r. władze komunistyczne zlikwidowały parafię rzymsko-katolicką w Kobryniu. Kościół przeznaczono na magazyn, a tamtejszy cmentarz wojskowy poległych żołnierzy w 1920 r. zrównano z ziemią. Ostatecznie teren przeznaczono na śmietnisko. Na skutek dwukrotnych pożarów w 1982 i 1988 r. świątynię doprowadzono do ruiny, której zniszczenia wynosiły $85 \%$. Na skutek starań tamtejszych katolików w Mińsku i Moskwie, w 1989 r. zdewastowany kościół w Kobryniu zwrócono katolikom. Został odbudowany dzięki miejscowym wiernym i pomocy z zagranicy. Uroczyście konsekrował go w lecie $1991 \mathrm{r}$. kard. Kazimierz Świątek.

\section{Opis fizyczny dokumentu rękopiśmiennego: Księga Inwentarzowa parafii Kobryń $1933^{10}$}

Dwa egzemplarze tego samego dokumentu, są to kopie maszynopisu, jednostronnie pisane przez fioletową kalkę maszynową, jeden dokument (najprawdopodobniej druga kopia) pisany na papierze drzewnym o gramaturze $80 \mathrm{~g} / \mathrm{m}^{2}$, drugi na papierze przebitkowym o gramaturze $30 \mathrm{~g} / \mathrm{m}^{2}$. Dokumenty składają się z luźnych kart, obłożone większa kartą złożoną na pół z wypisanym tytułem na wierzchniej stronie: INWENTARZ RZYMSKO KATOLICKIEGO KOŚCIOŁA PARAFIALNEGO w Kobryniu sporządzony dnia 21 sierpnia 1933 r. W obu przypadkach dokument zawiera 9 luźnych kart $(222 \times 356 \mathrm{~mm})$. Karty od pierwszej do ósmej są numerowane w lewym górnym rogu, dziewiąta nie ma oznaczenia strony. W pierwszym egzemplarzu, na stronie drugiej i piątej przy kolumnie liczb po prawej stronie ołówkiem naniesione są poprawki; strona druga: w rzędzie 2, 12 i 17; strona piąta: w rzędzie: 5 i 12. Na stronie piątej, także odręcznie ołówkiem naniesione są dopisy w linii 8, 12 i pod tekstem. Dopisy liczbowe (daty), ołówkiem kopiowym, wprowadzone zostały na stronach siódmej i ósmej przy i pod kolumnami liczb. Na karcie ósmej pod tekstem maszynowym kończącym się na wysokości $1 / 3$ strony widnieje odręczny tekst pisany czarnym atramentem $\mathrm{z}$ trzema oryginalnymi podpisami.

W egzemplarzu drugim (papier przebitkowy) odręczne dopisy liczbowe naniesione są tylko na stronie ósmej, pod tekstem maszynowym, tak jak w poprzednim egzemplarzu, odręczny tekst pisany czarnym atramentem z trzema oryginalnymi podpisami.

W obu kopiach na stronie ósmej, w lewym dolnym roku widać ślady po okrągłej czerwonej pieczęci, na ostatniej nieliczbowanej karcie w 1/3 wysokości znajdują się oryginalne podpisy takie same jak na poprzedniej stronie. Oba egzemplarze ujęte są w sztywne okładki $(226 \times 360 \mathrm{~mm})$ obleczone ciemno-szarym impregnowanym płótnem. Na górnej okładce pośrodku przyklejona jest biała kartka $(152 \times 67 \mathrm{~mm})$, z wypisaną czcionką maszynową informacją dotyczącą treści dokumentu, miejsca przechowywania oraz sygnatura, data 1926 została długopisem przekreślona i długopisem dopisana 1933. Taka sama informacja znajduje

${ }^{10}$ Dokument znajduje się w Archiwum Diecezjalnym w Drohiczynie, Zespół Archiwum Parafii Kobryń, Sygn. III/J/1. 
się na mniejszej karteczce przyklejonej u góry na grzbiecie okładki. W okładkach znajduje się jeszcze luźny dokument $(224 \times 176 \mathrm{~mm})$ datowany na $1926 \mathrm{r}$. Jest to druk Rady Gospodarczej w Pińsku numerowany L. 1485/89.R.G. wypisany po prawej stronie maszynowym pismem, a po lewej odręcznym, ukośnie z dołu do góry ołówkiem kopiowym i czarnym atramentem. Wszystkie dokumenty łącznie z okładkami zabezpieczone są tekturową białą teczką.

Stan zachowania na dzień 14 czerwca 2013 r. Karty zachowane są w dobrym stanie, jedynie dolny prawy róg we wszystkich kartach, w wyniku zamoczenia dokumentu, zaatakowany został przez mikroorganizmy. Niestety destrukcja ma tendencję powiększania się. Krawędzie wszystkich kart mają liczne niewielkie naddarcia. W obu dokumentach, w lewym górnym roku, przez wszystkie karty widać rdzawe ślady po metalowych spinaczach. Na okładkach, szczególnie na rogach i dłuższej krawędzi widoczne są także ślady zamoczenia, co spowodowało odbarwienia płótna.

$* * * * *$

[k. 1] Inwentarz rzymsko katolickiego kościoła parafialnego w Kobryniu.

Rzymsko Katolicki parafialny kościół kobryński położony przy ulicy 3-go Maja w Kobryniu wymurowany został z ofiar dobrowolnych przez księdza Antoniego Kisielewskiego proboszcza kobryńskiego w roku 1845 i 15-go sierpnia tegoż roku przez ks. [Antoniego] Kisielewskiego poświęcony a 1851 roku dnia 1 sierpnia konsekrowany przez biskupa wileńskiego Wacława Żylińskiego, pod wezwaniem Wniebowzięcia Matki Boskiej.

Długość $32 \frac{1}{2} \mathrm{mt}$.[metrów], szerokość 16 1/2 mt.[metrów], o dwóch wieżach, pokryty blachą żelazną, obie zaś wieże blachą ocynkowaną, sklepienia nawy głównej z desek, oparte na ośmiu filarach, posadzka murowana, trzy ołtarze snycerkiej ${ }^{11}$ roboty wyzłacane i posrebrzane. W ołtarzu wielkim obraz cudowny Pana Jezusa, w ołtarzu bocznym z prawej strony obraz Najświętszej Panny Ostrobramskiej, a ołtarzu po lewej stronie obrazy: św. Antoniego Padewskiego i św. Józefa, Oblubieńca Najświętszej Maryi Panny. Ambona ozdobnej roboty. Prezbiterium oddzielone od nawy głównej kratą żelazną, w nawie głównej po obu stronach ławki drewniane, wszystkich razem 30 . Konfesjonały 4, na chórze organy o głosach 13, zbudowane przez firmę Szymański ${ }^{12}$ w Warszawie 1900 roku, żyrandoli 4. Na

\footnotetext{
${ }^{11}$ Snycerstwo - artystyczne rzemiosło, sztuka rzeźbienia w drewnie, dawniej także w kamieniu.

${ }^{12}$ Szymański Józef (1828-1892) - organmistrz warszawski, uważany na przełomie XIX/XX w. za autorytet z dziedziny budownictwa organowego. Urodził się w Kocierzewie koło Łowicza. Był synem organisty Andrzeja. Zawodu uczył się u M. Malczewskiego. Prowadził od $1861 \mathrm{r}$. firmę organmistrzowską, działającą początkowo w Częstochowie, a od 1868 r. w Warszawie na ulicy Chłodnej. Od 1880 r. firma pracowała pod nazwą: Józef Szymański i Syn. W Warszawie, przy ul. Chłodnej 46 prowadził od 1890 r. także swój warsztat organomistrz Michał Kutrzyk (ur. 1866), wcześniej odbywający praktykę u Józefa Szymańskiego. Józef Szymański nagrodzony został złotym medalem na Wystawie Powszechnej w Warszawie w 1885 r. Za jego życia w jego firmie zbudowano 126 instrumentów. Zmarł w Warszawie. Józef Szymański, w: Encyklopedia muzyczna PWM, Sm-Ś Część Biograficzna, red. E. Dziębowska, Kraków 2007, s. 298.
} 
lewo od prezbiterium skarbiec, na prawo zakrystia, drzwi dębowych futrowanych - czworo, troje z zamkami wnętrznymi, czwarte zamykane na drąg od wewnątrz. Okien 14, z których 2 z żelaznymi kratami.

Księga Inwentarzowa parafii Kobryń 1933

\section{Sprzęty kościelne}

\section{Aparaty:}

Ornatów białych z rekwizytami

Ornatów czerwonych z rekwizytam

Ornatów zielonych z rekwizytami

Ornatów fioletowych z rekwizytami

Ornatów czarnych z rekwizytami

Ornatów z pasów słuckich

[k. 2] Dalmatyk

Kap białych

Kap czerwonych

Kapa zielona

Kapa fioletowa

Kap czarnych

Stół biało-fioletowych

Stół rozmaitych

Burs białych do chorych

Bursa filetowa do Olejów św[iętych]

Welonów do Przenajśw[iętszego] Sakramentu

Firanek do tabernakulum

Baldachim o czterech kijach

Baldachim o dwóch kijach

Umbrakulum ${ }^{13} \mathrm{w}$ złoconej oprawie

Całun

Chorągwi białych

Chorągwi czerwonych

Chorągwi żałobnych

\section{Bielizna:}

Obrusów ołtarzowych

Obrusów do kratek

Serwet szydełkowej roboty

$\mathrm{Alb}$

Komży

Komży dla ministrantów

[k. 3] Humerałów

Pasów
7

7

4

4

3

2

3 pary

3

1

1

1

2

5

3

2

1

3

4 pary

1 stary

1

1

1

6

3

3

\section{8}

5

2

9

6

22

18

4

${ }^{13}$ Umbraculum - parawanik z motywami eucharystycznymi, zasłaniający monstrancję z wystawionym Najświętszym Sakramentem, podczas uroczystych obrzędów liturgicznych. 
Ręczników większych

Ręczników

Korporałów

Palek

Puryfikaterzy

\section{Sprzęt kruszcowy:}

Monstrancja duża cała wyzłacana 1

Monstrancja mniejsza cała wyzłacana $\quad 1$

Monstrancja częściowo wyzłacana 1

(wypożyczona do kościoła Zbirohowskiego ${ }^{14}$ )

Kielichów wyzłacanych z patenami 2

Kielichów starych 4

Puszek 2

Patena do Komunii [Świętej] 1

Ampułek metalowych 4

Ampułka do chrztu 1

Miseczka do chrztu 1

Kociołek do wody święconej 1

Kropidło 1

Trybularzy ${ }^{15} \mathrm{z}$ łódkami 2

Lichtarzy frażetowych ${ }^{16} \quad 22$

Kandelabrów ${ }^{17} \quad 2$ pary

Pacyfikałów 2

[k. 4] Krzyż procesjonalny frażetowski 1

Kociołków do wody chrzcielnej 2

Kocioł z miedzi do wosku 1

Lichtarzy mosiężnych 6

Lichtarzy cynowych $\quad 12$

Lichtarzy drewnianych 2

Tacek 3

Patena do chorych 1

${ }^{14}$ Zbirohi - kościół parafialny pw. Trójcy Przenajświętszej, drewniany, ufundowany w 1620 r. przez rodziny Sapiehów i Paców. W 1865 r. zamknięty przez władze carskie. W 1920 r. rewindykowany, w 1925 r. odrestaurowany. Parafia Zbirohi w powiecie brzeskim, była sąsiednią parafią kościoła w Kobryniu (w powiecie kobryńskim), oddaloną o 36 kilometrów. Spis kościołów i duchowieństwa diecezji pńskiej w R. P. 1935, Pińsk 1935, s. 111-112

15 Trybularz - kadzielnica, naczynie, do którego na rozżarzone węgle sypie się kadzidło, służące do okadzania: ołtarza, darów ofiarnych, Najświętszego Sakramentu, Ewangeliarza, krzyża, figur, celebransa, uczestników liturgii. B. Nadolski, Kadzielnica, trybularz, w: EK, t. 8, Lublin 2000, kol. 319.

${ }^{16}$ Frażetowy, frażetowski, platerowany. Platerować (niem. platieren) - to chemiczna technologia polegająca na pokrywaniu metalu mniej szlachetnego warstwą metalu szlachetniejszego, np. miedź folią srebrną lub złotą.

${ }^{17}$ Kandelabr - duży, stojący, kilkuramienny świecznik często bogato zdobiony. 
Naczynie do Przenajśw[iętszego] Sakr[amentu] do chorych 1

Żelazko do pieczenia opłatków

Pochodni frażetowskich

Pochodni

Zegar ścienny

Ampułek szklanych

Ampułek metalowych

Dzwon 360 kil[ogramów] wagi

Dzwon 150 kil[ogramów] wagi

Dzwonów mniejszych

Dzwonek przy zakrystii

Dzwonków małych

Votów w ołtarzu wielkim

Votów w ołtarzu Matki Boskiej

Votów w ołtarzu św. Józefa i Antoniego

3

Stacji Drogi Krzyżowej z terakoty

Figura Zmartwychwstania (z gipsu)

1

Figura Pana Jezusa do grobu (z gipsu)

1

Figurek do żłóbka (z gipsu)

Krzyży procesjonalnych z drzewa

Lichtarz do paschału

[k. 5] Klęczników z drzewa

Klęcznik - konfesjonał

Krzesło dla celebransa

Katafalk o pięciu stopniach

Kolumny do katafalku

Karawan

Obrazów na płótnie

Obraz Matki Boskiej Smoleńskiej

(na drzewie w srebrnej szacie, ładnej roboty, ofiara Zbirochowskich 1830 roku)

Pulpitów ołtarzowych z drzewa

Pulpitów-poduszek

Ołtarzyków-feretronów

Dywanów

\section{Księgi liturgiczne:}

Mszały

Mszał żałobny

Rytuały

Kancjonał

Ewangeliczka

[k. 6] Kościół znajduje się w dużym parku kościelnym, ogrodzonym od ulicy 3-Maja murem, od ul. Kościelnej - płotem z siatki drucianej, z dwóch przeciwległych stron sztachetami. W ogrodzeniu kościelnym jedna kaplica murowana, 
pod wezwaniem św. Anny, pokryta blachą cynkową. Druga kapliczka drewniana pokryta blachą żelazną.

Na wschód od kościoła w kilkudziesięciu metrach leży stary cmentarz parafialny, ogrodzony w latach 1931-1932 murem, siatką z drutu ocynkowanego i sztachetami. Na cmentarzu jest kaplica murowana, kryta dachówką.

Drugi cmentarz na północnym krańcu miasta odległy od kościoła około trzech kilometrów, ogrodzony murem, siatką drucianą i sztachetami.

Przy kościele plebania murowana pokryta gontami ${ }^{18}$. Drzwi zewnętrznych dwoje, drzwi wewnętrznych 15, okien 18 .

Obok plebanii budynek z drzewa pokryty gontami; jedna część tego budynku służy jako skład na drzewo, z niej wejście do murowanej piwnicy, druga połowa służy jako spichlerz.

W kilkunastu metrach od strony południowo-wschodniej znajduje się obora i stajnia z drzewa pokryta gontami w 1932 r., a nieco dalej położona stodoła z drzewa, pokryta gontami w $1931 \mathrm{r}$.

Plebania położona jest w ogrodzie owocowym - starym i młodym. Ten ostatni założony w latach 1926-1932.

Na dziedzińcu przed plebanią studnia betonowa zbudowana w 1926 r. Przy obu cmentarzach, starym i nowym, są dwa domy, przeznaczone na mieszkanie dla stróży cmentarnych, oba z drzewa pokryte gontami.

Naprzeciw bramy kościelnej znajduje się dom dla obsługi kościelnej, zbudowany z drzewa i pokryty gontami. Na tymże placu drugi dom kościelny z drzewa pokryty dachówką i w mniejszej części gontami, przy każdym z tych domów znajduje się po jednej szopie $\mathrm{z}$ drzewa.

Podług planów sporządzonych w roku 1928 do beneficjum kościoła kobryńskiego należy 80 hektarów ziemi kościelnej, oprócz tego kościół kobryński ma wielką ilość placów czynszowych w obrębie miasta, lecz dowody na te place zaginęły w czasie wojny światowej.

\section{[k. 7] Obligacje duchowne}

Oprócz zobowiązań notowanych w starych inwentarzach w lipcu 1926 r. za pośrednictwem ks. [Pawła] Dołżyka ${ }^{19}$ została złożona kwota 164 zł. 73 gr. (sto sześćdziesiąt cztery złote 73 gr.) która to suma jest obecnie złożona w Banku Spółdzielczym w Kobryniu, z zobowiązaniem odprawiania każdego roku Mszy św. za duszę śp. Borkowskiej.

${ }^{18}$ Gont - deszczułka klinowa używana do pokrywania dachów lub szalowania zewnętrznych ścian budynków.

${ }^{19}$ Ks. Dołżyk Paweł - kapłan diecezji pińskiej. Urodził się w 1871 r., w 1897 r. przyjął święcenia kapłańskie. Jako proboszcz parafii Łubin, w dekanacie bielskim, w archidiecezji wileńskiej, wybudował w 1910 r. wspólnie z parafianami kościół pw. Wniebowzięcia NMP. Od 1919 r. był proboszczem parafii Wniebowzięcia NMP w Derewnej, dekanat Stołpce. Spis kościołów i duchowieństwa diecezji pińskiej w R. P. 1933 i 1934, Pińsk 1933, s. 166. 


\section{Porządek nabożeństwa:}

W niedziele i dni świąteczne pierwsza Msza Święta t[o] z[naczy] uczniowska, odprawia się o godz. 9-tej, suma zaś o godz. 11-ej z kazaniem po ewangelii, nieszpory o godz. 5-ej, w wigilię świąt i w soboty o godz. 6-ej.

Majowe i czerwcowe nabożeństwo bywa odprawiane o godz. 6-ej, październikowe, z wystawieniem Przenajświętszego Sakramentu w monstrancji, też o 6-ej.

W każdą I-szą niedzielę miesiąca oraz w święta Matki Boskiej suma odprawia się z wystawieniem Przenajświętszego Sakramentu.

We wszystkie piątki o godz. 8-ej bywa odprawiana Msza św. przed cudownym obrazem Zbawiciela (Buchowieckiego), z odmawianiem w każdy I-szy piątek miesiąca litanii do Najświętszego Serca Jezusowego, w inne zaś piątki odmawia się litanię o Imieniu Jezus.

Dnia 14-go sierpnia o godz. 5. pp [po południu] rozpoczyna się 40-to godzinne nabożeństwo.

Parafia kobryńska graniczy z parafiami: Horodecką, Kiwatycką, Zbirohowską, Małorycką i Dywińską.

\section{Archiwum parafialne:}

Z najścia bolszewickiego roku 1920 archiwum parafialne zostało w znacznej części zniszczone.

\section{Księgi metryczne:}

Urodzonych 1829-1837

Urodzonych 1839-1848

Urodzonych 1848-1862

Urodzonych 1862-1867

Urodzonych 1867-1880

Urodzonych 1887-1894

Urodzonych 1895-1898

Urodzonych 1898-1900

Urodzonych 1900-1903

Urodzonych 1903-1914

Urodzonych 1915-1927

Urodzonych 1927-1933

Urodzonych 1935-1936 (dopisane ołówkiem w późniejszym czasie)

[k. 8] Ślubnych 1827-1849

Ślubnych 1894-1882

Ślubnych 1882-1887

Ślubnych 1913-1933

Ślubnych 1934-1936 (dopisane ołówkiem w późniejszym czasie)

Zmarłych 1881-1887

Zmarłych 1888-1904

Zmarłych 1904-1915

Zmarłych1915-1933

Zmarłych 1934-1936 (dopisane ołówkiem w późniejszym czasie) 
Egzaminów przedślubnych 1856-1864

Egzaminów przedślubnych 1883-1898

Egzaminów przedślubnych 1906-1920 (dopisane ołówkiem)

Egzaminów przedślubnych 1921-1926 (dopisane ołówkiem)

Egzaminów przedślubnych 1926-1933 (dopisane ołówkiem)

Nawróconych 1922-1923

Urodzonych kościoła krupczyckiego1707-1817 (dopisane ołówkiem)

Urodzonych kościoła krupczyckiego 1848-1866

Ślubnych 1822-1839 (dopisane ołówkiem)

Zmarłych 1827-1848 (dopisane ołówkiem)

Urodzonych Buchowieckiego ${ }^{20}$ kościoła 1707-1792 (dopisane ołówkiem)

Dnia 21 sierpnia 1933 r. kościół kobryński podług niniejszego inwentarza zdałem. Ks. dr [Józef] Kuczyński ${ }^{21}$.

Kościół kobryński z przynależnym doń inwentarzem przyjąłem, ks. dr [Jan] Węckiewicz ${ }^{22}$.

W mojej obecności: ks. Bronisław Kiełbasa ${ }^{23}$, dziekan brzeski, delegat kurii.

Kobryń, dn. 21 sierpnia 1933 r.

${ }^{20}$ Murowany kościół parafialny w Buchowiczach (dekanat Kobryń, powiat Brześć) dominikanów, zabrany przez prawosławnych w 1864 r., dotychczas nie rewindykowany. Spis kościołów $i$ duchowieństwa diecezji pińskiej w R. P. 1933 i 1934, Pińsk 1933, s. 113.

${ }^{21}$ Ks. Kuczyński Józef (1879-1942/1943) - kapłan diecezji pińskiej, doktor prawa kanonicznego. Urodził się w 1879 r., święcenia kapłańskie przyjął w 1903 r. Do 1933 r. był proboszczem w Kobryniu, skąd przeszedł do parafii pw. św. Kazimierza we Wsielubiu, dekanat Nowogródek. Za pomoc jeńcom rosyjskim i Żydom został aresztowany dnia 28 czerwca 1942 r. przez Niemców i rozstrzelany 31 lipca tego roku koło Nowogródka. W 1944 r. jego ciało zostało przeniesione do Wsielubia i złożono na starym cmentarzu w pobliżu kościoła. Spis kościołów i duchowieństwa diecezji pińskiej w R. P. 1933 i 1934, Pińsk 1933, s. 148; W. Jacewicz, J. Woś, Martyrologium polskiego duchowieństwa rzymskokatolickiego pod okupacją hitlerowska w latach 1939-1945, z. 1, Warszawa 1977, s. 276.

${ }^{22}$ Ks. Węckiewicz Jan - kapłan diecezji pińskiej, doktor Świętej Teologii, kanonik honorowy Kapituły Wileńskiej, sędzia synodalny Sądu Biskupiego w Pińsku. Urodził się w 1884 r., święcenia kapłańskie przyjął w 1906 r. Od 1933 r. był proboszczem i dziekanem w Kobryniu. Spis kościołów i duchowieństwa diecezji pińskiej w R. P. 1933 i 1934, Pińsk 1933, s. 18, $20,24$.

${ }^{23}$ Ks. Bronisław Kiełbasa - kapłan diecezji pińskiej, kanonik, kanclerz Kurii Diecezjalnej Pińskiej. Urodził się w 1883 r., święcenia kapłańskie przyjął w 1906 r. Od 1933 r. był kanclerzem Kurii Diecezjalnej Pińskiej. Spis kościołów i duchowieństwa diecezji pińskiej w R. P. 1933 i 1934, Pińsk 1933, s. 17, 19, 21. 


\section{Opracowania}

\section{BIBLIOGRAFIA}

Biskupstwo Wileńskie, opr. J. Kurczewski, Wilno 1912.

Brzozecki Sławomir, Żyliński Wacław, w: Encyklopedia Katolicka, t. 20, Lublin 2014, kol. 1654-1655.

Jacewicz Wiktor, Woś Jan, Martyrologium polskiego duchowieństwa rzymskokatolickiego pod okupacja hitlerowska w latach 1939-1945, z. 1, Warszawa 1977.

Kobryń, w: Słownik Geograficzny Królestwa Polskiego, t. 4, Warszawa 1883, s. 205-207.

Kumor Bolesław, Granice metropolii i diecezji polskich (966-1939), Lublin 1969-1971.

Mikhailik Larysa, Kościót katolickie na Grodzieńszczyźnie 1939-1956, Warszawa 2008.

Nadolski Bogusław, Kadzielnica, trybularz, w: Encyklopedia Katolicka, t. 8, Lublin 2000, kol. 319.

Litak Stanisław, Kościót łaciński w Rzeczypospolitej około 1772 roku, Lublin 1996.

Spis kościołów i duchowieństwa diecezji pińskiej w R. P. 1933 i 1934, Pińsk 1933.

Spis kościołów i duchowieństwa diecezji pńskiej w R. P. 1935, Pińsk 1935.

Szymański Józef, w: Encyklopedia muzyczna PWM, Sm-Ś Część Biograficzna, red. E. Dziębowska, Kraków 2007, s. 298.

Wolski Jan, w: Niech świadectwo nie będzie zapomniane. Losy Kościoła katolickiego na Białorusi w latach 1917-1953, red. R. Wierna, Grodno 2000, s. 82.

\section{Netografia}

https://pl.wikipedia.org/wiki/Hieronim_Wo\%C5\%82\%C5\%82owicz (dostęp: 15.05.2018).

\section{INWENTARZ RZYMSKOKATOLICKIEGO KOŚCIOLA PARAFIALNEGO W KOBRYNIU Z DNIA Z 21 SIERPNIA 1933 ROKU}

\section{Streszczenie}

Po zniszczeniu w 1812 r. parafialnego kościoła rzymskokatolickiego w Kobryniu, wybudowany został nowy przez parafian pod kierunkiem proboszcza ks. Antoniego Kisielewskiego i przez niego poświęcony w sierpniu $1845 \mathrm{r}$., konsekrowany został w $1851 \mathrm{r}$. przez biskupa wileńskiego Wacława Żylińskiego. Prezentowany inwentarz Parafii Wniebowzięcia NMP w Kobryniu pochodzi z lat międzywojennych II Rzeczypospolitej. Inwentarz sporządził jego proboszcz ks. Józef Kuczyński dnia 21 sierpnia 1933 r. i według tego inwentarza przejął parafię kobryńską z przynależnym inwentarzem ks. Jan Węckiewicz, nowy proboszcz, w obecności ks. Bronisława Kiełbasy, delegata kurii pińskiej i dziekana brzeskiego.

Słowa kluczowe: Kobryń; historia Kresów Wschodnich; historia Kościoła; wizytacje kanoniczne parafii 


\title{
ІНВЕНТАР РЫМА-КАТАЛЦКАГА ПАРАФІЯЛЬНАГА КАСЦЁЛА Ў КОБРЫНЕ 321 ЖНІЎНЯ 1933 Г.
}

\begin{abstract}
Скарачэнне
Пасля знішчэння ў 1812 г. рыма-каталіцкага парафіяльнага касцёла ў Кобрыне, парафіянамі пад кіраўніцтвам пробашча кс. Антонія Кісялеўскага быў пабудаваны новы. Гэты касцёл быў асвечаны ў жніўні 1845 г. пробашчам кс. А. Кісялеўскім і кансэкраваны біскупам Віленскім Вацлавам Жылінскім. Прадстаўлены інвентар парафіi Унебаўзяцця Найсвяцейшай Марыі Панны ў Кобрыне адносіцца да міжваенных гадоў II Рэчыпаспалітай. Інвентар склаў пробашч парафіi кс. Юзаф Кучынскі 21 жніўня 1933 г. і паводле гэтага інвентара кобрынскую парафію з належнай да яе маёмасцю прыняў новы пробашч кс. Ян Венцкевіч у прысутнасці делегата Пінскай курыіi, Брэсцкага дзекана кс. Браніслава Келбасы.
\end{abstract}

Перевод Лауры Михайлик

\section{ИНВЕНТАРЬ РИМСКО-КАТОЛИЧЕСКОГО ПРИХОДСКОГО КОСТЕЛА В КОБРИНЕ С 21 АВГУСТА 1933 Г.}

\section{Содержание}

После уничтожения в 1812 г. римско-католического приходского костела в Кобрине, прихожанами под руководством настоятеля о. Антония Киселевского был построен новый. Этот костел был освящен в августе 1845 г. настоятелем о. А. Киселевским и консекрирован епископом Виленским Вацлавом Жилинским. Представленный инвентарь прихода Успения Пресвятой Девы Марии в Кобрине относится к межвоенному периоду II Речипосполитой. Инвентарь составил настоятель прихода о. Иосиф Кучинский 21 августа 1933 г. и на основании этого инвентаря кобринский приход с принадлежащим ему имуществом принял новый настоятель о. Иоанн Венцкевич в присутствии делегата Пинской курии, Брестского декана о. Бронислава Келбасы. 


\title{
THE INVENTORY OF THE ROMAN CATHOLIC PARISH CHURCH IN KOBRYŃ OF 21 AUGUST 1933
}

\begin{abstract}
Summary
After the destruction of the Roman Catholic parish church in Kobryń in 1812, a new church was built by the parishioners under the guidance of parish priest Antoni Kisielewski who also blessed it in August 1845, the bishop of Vilnius Wacław Żyliński consecrated it in 1851. The presented inventory of the Parish of the Assumption of Mary in Kobryń comes from the interwar period of the Second Polish Republic. The inventory was made by parish priest Rev. Józef Kuczyński on 21 August 1933 and according to this inventory, Rev. Jan Węckiewicz took over the parish of Kobryń in the presence of Rev. Bronisław Kiełbasa, the delegate of the curia of Pińsk and the dean of Brest.

Keywords: Kobryn; the history of the Eastern Borderlands; the history of the Church; canonical visitations of parishes
\end{abstract}

